\title{
Effect of Split N-Fertilizer Application on Soil Quality and Maize Yield of Tropical Alfisol
}

\author{
G.O. Dayo-Olagbende
}

\author{
Crop, Soil and Pest Management, School of Agriculture and Agricultural Technology, Federal \\ University of Technology, Akure, Nigeria.
}

phemmieisrafel@gmail.com

\author{
Keywords: Split application, Urea, Fertilizer, Biomass, Yield
}

\begin{abstract}
A field experiment was conducted to determine the effect of split application of nitrogen fertilizer on soil properties and maize yield. Two sites at Apatapiti layout, South gate of the Federal University of Technology Akure were used as the experimental sites. The experiment was designed in a randomized-complete-block design arrangement with three replications. The treatments consisted of urea applied at four levels of split application $\left(0 \mathrm{~kg} \mathrm{ha}^{-1}, 60 \mathrm{~kg} \mathrm{ha}^{-1}\right.$ basal application, $30 \mathrm{~kg} \mathrm{ha}^{-1}$ basal application $+30 \mathrm{~kg} \mathrm{ha}^{-1}$ applied at 15 days after planting, $30 \mathrm{~kg} \mathrm{ha}^{-1}$ basal application $+20 \mathrm{~kg} \mathrm{ha}^{-1}$ applied at 15 days after planting $+10 \mathrm{~kg} \mathrm{ha}^{-1}$ applied at 30 days after planting). The plot size was $2 \mathrm{~m}$ x $2 \mathrm{~m}$ with $1 \mathrm{~m}$ space between plots and blocks. Maize (Zea mays L. var. TZB-SR) was planted at $75 \mathrm{~cm}$ by $25 \mathrm{~cm}$ spacing and 10 were sampled per unit for yield parameters. Split application of urea $\left(30 \mathrm{~kg} \mathrm{ha}^{-1}\right.$ basal application $+20 \mathrm{~kg} \mathrm{ha}^{-1}$ applied at 15 days after planting $+10 \mathrm{kgha}^{-1}$ applied at 30 days after planting) significantly $(\mathrm{p}>0.05)$ increased $\mathrm{N}$ content of the soil. There was no significant $(\mathrm{p}>0.05)$ difference with regard to other nutrients. Soil $\mathrm{pH}$ was significantly $(p>0.05)$ reduced as a result of urea application in all treatments. Split urea fertilizer application retained a considerable amount of nitrogen in soil even after the harvest of maize. Exchangeable cations were not significantly different from one another as well as CEC. Split application of urea (30 $\mathrm{kg} \mathrm{ha}^{-1}$ basal application $+20 \mathrm{~kg} \mathrm{ha}^{-1}$ applied at 15 days after planting $+10 \mathrm{~kg} \mathrm{ha}^{-1}$ applied at 30 days after planting) gave the highest grain yield of maize for both sites. Also, plant biomass of both split application were better than the basal application and control.
\end{abstract}

\section{Introduction}

Soil arises as a result of the influence of climate, relief, biotic activities and parent materials interacting over time [6]. Soil is formed over very long period of time from igneous or sedimentary rocks, volcanic ash, sand or peat. Plants need water, carbon dioxide and a range of trace minerals known as 'nutrients' to grow. Soil is the major source of these nutrients and water. However, land degradation became and remained a global issue in the 21 st century as it affects the environment, agronomic productivity, food security, and quality of life [4]. The only answer to depletion of nutrient is to bring fresh nutrients into an area from some richer source. Fortunately, natural processes have made these major nutrients available in abundance in certain locations around the world. All industrially manufactured nitrogen fertilizers obtain their nitrogen from the atmosphere. This is done using the Haber process, in which dihydrogen and dinitrogen at high temperature and pressure are combined over a catalyst, which speeds up the reaction forming ammonia. Although the use of synthetic fertilizers to produce staple food crops has generally been restricted to only a few farms endowed with resources [14] and with high off-farm income [13], the actual practice of agriculture with the use of chemical fertilizers is still one of the main causes of today's environmental diseases. Although fertilizer application has produced high increases in crop yields, they have also had negative effects such as losses of thousands of hectares of fertile land, soil degradation and increases of more virulent pathogens [3]. Fertilizers contain three primary plant nutrients: mostly nitrogen and phosphorous with smaller amounts of potassium. The first two are the most important pollutants. Nitrogen fertilizers can contaminate groundwater because nitrates are highly soluble in water. When natural sources contribute a high concentration of nitrate to the groundwater it is usually as a result 
of anthropogenic disturbance. One example of this is the effect of forested areas on the leaching of nitrate to the groundwater. Natural, mature forests conserve nitrogen but human disturbances can lead to nitrate pollution of the groundwater. However, while this is a potential problem for groundwater, agriculture still represents a higher source of nitrogen compared to forests [7]. At high levels, nitrates can poison humans, particularly children. Lower levels of nitrates can also be deadly to amphibians. Certain forms of nitrogen are released as gases, contributing to acid rain and climate change [12]. Rainwater runoff brings fertilizers into streams, rivers, lakes and oceans. This technology is also responsible for eutrophication of bodies of water, increases in nitrate levels in ground and surface water, and increments of pesticide residues in water, soils and food [15]. Not all organisms in a lake, pond or coastal delta are equally prepared to take advantage of the new nutrients because in actual sense, fertilizer does not make fish grow bigger, rather the biggest change occurs in algae populations, which flourish. Algal blooms cover the surface of the water so sunlight does not penetrate as far down as it typically would, reducing the ability of underwater plants to perform photosynthesis and produce oxygen. Dying algae feed microorganisms, which deplete more oxygen. Fish species such as trout and salmon die when dissolved oxygen is too low, while other species like carp often take over. A few algae species produce toxins that can kill fish, birds, and mammals and cause health problems for humans. Other algae species are not exactly toxic, but they cause bad smells or ruin the taste of fish caught in the same waters. Humans are most at risk when they eat contaminated seafood. The use of organic wastes (OW) as alternative to chemical fertilizers has been employed and found not only to result in an economic benefit to the small-scale farmer but it also reduces pollution due to reduced nutrient run-off, and $\mathrm{N}$ leaching [9]. However, when used in huge amounts, organic residues produced by agricultural activities can become environmental pollutants since they increase salinity levels, nitrate lixiviation rate into underground and drain water as well as phosphate concentration in surface water [5]. In addition, organic residues are associated with accumulation of lignin, aromatic oils and resins [17], and several pests, weeds and diseases have been disseminated [1] and cases of toxicity in cultivated plants have increased [19]. Fertilizers, whether they are artificial or organic, can cause serious problems if they contaminate freshwater and marine ecosystems. Fertilizer pollution is harder to regulate and reduce than many other kinds of water pollution because it is a type of nonpoint source pollution. A point source which comes from one definable location, such as a factory is easier to track. But fertilizers are used on private lawns, in agricultural fields and on golf courses. Manure contains high levels of nitrogen and phosphorus and causes the same ecological problems as artificial fertilizers. Even if fertilizers are not used near a body of water, rainfall eventually washes them into streams and rivers. As things stand, reliance on fertilizers particularly chemical fertilizers has to be reduced, more so that many farmers suffer as a result of price volatility and given the fact that the inefficiency of fertilizer application is also a major problem. By some estimates, as much as 70 percent of nitrogen fertilizer applied to crops in developing nations go to waste and lost to runoff or released into the atmosphere, contributing to coastal "dead zones," global warming, ozone layer depletion and other problems [18]. Hence, a means to modify the method of fertilizer application such that it is available when the plants need it, thereby reducing the amount that goes into waste is important. The objective of this work is therefore to determine the effect of split nitrogen fertilizer application on soil physicochemical properties and maize yield.

\section{Materials and Methods}

\section{Experimental Site}

A concurrent experiment was carried out between June-August 2014 at two locations at Apatapiti Layout, Akure, Southwest Nigeria (Latitude $7^{0} .30^{1}$ and Longitude $5^{0} .15^{1}$ ). The area experiences a tropical climate with distinct wet and dry seasons. Mean annual rainfall is about $1524 \mathrm{~mm}$. The annual total sunshine hour is about 2000 hours while annual relative humidity is $80 \%$. 


\section{Planting Material}

White Maize variety (TZB-SR), a late maturing cultivar obtained from the International Institute of Tropical Agriculture (IITA) Ibadan, Oyo State, was used for the experiment.

\section{Experimental Design}

A land area of $13 \mathrm{~m} \times 10 \mathrm{~m}$ was ploughed and harrowed. The harrowed land was marked into twelve (12) experimental units, with each unit having a size of $2 \mathrm{~m} \mathrm{X} 2 \mathrm{~m}$ and $1 \mathrm{~m}$ spacing was allowed between alleyways also between blocks. This resulted in twenty plant stands per site at $75 \mathrm{X}$ $25 \mathrm{~cm}$ spacing, out of which ten plants were randomly tagged for observation. Weeds were controlled manually at three weeks intervals. The experiment was laid out in a Randomised Complete Block Design (RCBD) with four treatments. The treatments involved four levels of Urea fertilizer $\left(0 \mathrm{~kg} \mathrm{ha}{ }^{-1}, 60 \mathrm{~kg}\right.$ applied at planting, $30 \mathrm{~kg}$ applied at planting $+30 \mathrm{~kg}$ applied at fifteen days after planting (DAP), $30 \mathrm{~kg}$ applied at planting $+20 \mathrm{~kg}$ applied at fifteen DAP $+10 \mathrm{~kg}$ applied at $30 \mathrm{DAP}$ ). Single superphosphate was placed five $(5) \mathrm{cm}$ below maize seed at planting at a constant rate of $45 \mathrm{~kg}$ P to guard against soil induced phosphorus deficiency.

\section{Data Collection}

Ten plants were tagged for observation, Yield parameters (weight of cob (g), weight of wet grain (g), weight of dry grain (g), 1000-grain weight $(\mathrm{g})$, shoot and root biomass (g) were collected at harvest. Harvesting of maize cob was done 12 weeks after planting.

\section{Laboratory Analyses}

Surface soil sample $(0-15 \mathrm{~cm})$ was collected randomly and samples from the same units were bulked together from which a composite sample was taken. The sample was air-dried and passed through $2 \mathrm{~mm}$ sieve and analyzed for major physical and chemical properties. Soil $\mathrm{pH}$ was determined in 1:2 soil solution, particle size distribution was carried out using hydrometer method. Organic carbon and organic matter were determined using Walkey-Black wet oxidation method (1934). Exchangeable cations were extracted with neutral normal ammonium acetate solution. Exchangeable $\mathrm{K}$ and sodium ( $\mathrm{Na}$ ) were read with flame photometer while $\mathrm{Ca}$ and $\mathrm{Mg}$ were determined using Atomic Absorption Spectrophotometer. Percentage $\mathrm{N}$ was determined using the Kjeldahl method and Phosphorus (P) by Bray and Kurtz method [2]. Soil moisture content was determined using the ovendry method. Bulk density was determined using core sampler method, and infiltration was determined using the cylindrical core method, with the core driven $10 \mathrm{~cm}$ into the soil and held at a fallen head condition for a duration of 30 minutes. Cation Exchange Capacity (CEC) was calculated as the summation of exchangeable cations, Soil Porosity was calculated using the following formula:

$$
\text { Soil porosity }=\left(1-\frac{\mathrm{db}}{\mathrm{dp}}\right) \times 100 \text {, }
$$

where $\mathrm{db}$ is bulk density and dp is particle density, the C: $\mathrm{N}$ Ratio was determined.

\section{Statistical Analysis}

Results were subjected to Analysis of Variance (ANOVA) using Statistical Analysis System (SAS), and mean separation was done using Duncan's Multiple Range Test (DMRT).

\section{Results and Discussion}

\section{Pre-experiment Soil Physical and Chemical Properties:}

Table 1 shows the pre-experiment physical and chemical properties of the soils of the two sites used for the experiment. The soil in Site 1 was slightly acidic $(\mathrm{pH} 6.23)$, sandy clay loam in texture with a sand content of $51.7 \mathrm{~g} / \mathrm{kg}$, clay content of $26.3 \mathrm{~g} / \mathrm{kg}$ and silt content of $22.0 \mathrm{~g} / \mathrm{kg}$ and has moderate organic matter content $(2.57 \%)$. Total $\mathrm{N}(0.20 \%)$ was at medium level (Anon, 2006) which is similar to the mean value for soils in southwestern Nigeria (FMANR, 1990). Exchangeable K 
$(0.19 \mathrm{cmol} / \mathrm{kg})$ was very low being below $0.20 \mathrm{cmol} / \mathrm{kg}$ while available $\mathrm{P}$ was also low with a value of $5.3 \mathrm{mg} / \mathrm{kg}$.

The soil in Site 2 was moderately acidic ( $\mathrm{pH}$ 6.02), sandy loam in texture with a sand content of $68.8 \mathrm{~g} / \mathrm{kg}$, clay content of $5.7 \mathrm{~g} / \mathrm{kg}$ and silt content of $26.5 \mathrm{~g} / \mathrm{kg}$ with low organic matter content $(1.42 \%)$. The total $\mathrm{N}$ was $0.14 \%$ which was moderately low. Exchangeable $\mathrm{K}$ at $0.11 \mathrm{cmol} / \mathrm{kg}$ is considered as very low and available $\mathrm{P}(3.8 \mathrm{mg} / \mathrm{kg})$ was low.

Table 1: Physico-chemical properties of the soils at the sites before the experiment

\begin{tabular}{lcc}
\hline Properties & Site 1 & Site 2 \\
\hline Soil $\mathrm{pH}$ (Water) & 6.23 & 6.02 \\
Sand g/kg & 51.7 & 68.8 \\
Silt g/kg & 22.0 & 26.5 \\
Clay g/kg & 26.3 & 5.7 \\
Textural Class & Sandy Clay Loam & Sandy Loam \\
Moisture Content \% & 26.2 & 21.4 \\
Bulk Density $(\mathrm{g})$ & 1.36 & 1.25 \\
Total porosity \% & 46.9 & 51.2 \\
Infiltration (cm/hr) & 6.4 & 13.6 \\
Dispersion Ratio & 75.2 & 74.6 \\
CEC(cmol/kg) & 5.44 & 4.27 \\
Base Saturation \% & 96.3 & 96.7 \\
Organic carbon \% & 1.49 & 0.82 \\
Organic matter \% & 2.57 & 1.42 \\
Total N \% & 0.20 & 0.14 \\
C/N Ratio & 7.00 & 6.20 \\
Available P (mg/kg) & 5.3 & 3.8 \\
K (cmol/kg) & 0.19 & 0.11 \\
Na(cmol/kg) & 0.25 & 0.14 \\
Ca(cmol/kg) & 0.30 & 0.21 \\
Mg(cmol/kg) & 0.13 & 0.09 \\
Exchangeable Acidity & 1.42 & 0.98 \\
\hline
\end{tabular}

Effects of split urea applications on soil physical properties at the end of harvest of maize:

Table 2 shows the effects of urea application on the physical properties of soils at Sites 1 and 2 at the end of harvest of maize. At Site 1, there was no significant $(p>0.05)$ difference in moisture contents between treatments $T_{1}, T_{2}$ and $T_{3}$ but the three were significantly $(p>0.05)$ higher than the control. At site $2, \mathrm{~T}_{3}$ gave the highest soil moisture content. There was no significant $(\mathrm{p}>0.05)$ difference between $T_{1}$ and $T_{2}$ while the control gave the least moisture content. This agrees with the work of Zhong et al. [8] who reported that $\mathrm{N}$ fertilizer had no significance on soil moisture content. At site $1, T_{2}$ and $T_{3}$ had a higher bulk densities than the control, but they were not significantly $(p>$ $0.05)$ different from each other. Treatments at Site 2 showed no significant $(p>0.05)$ difference from each other This agrees with the work of Malik et al. [11] who reported that no significant difference was observed on application of fertilizer on bulk density. At site 1 , the control and $\mathrm{T}_{1}$ gave the highest total porosity while $T_{2}$ and $T_{3}$ gave the least. There was no significant $(p>0.05)$ difference between the control, $T_{1}$ and $T_{2}$ for total porosity at Site 2 , while $T_{3}$ had the lowest porosity this variations can be attributed to the two different soil texture that was used. The results at Site 1 showed that the control and $T_{3}$ had the highest infiltration rates and $T_{1}$ recorded the lowest. At Site $2, T_{1}$ gave the highest value for infiltration rate while the control gave the least. However, $\mathrm{T}_{1}$ was not significantly $(p>0.05)$ different from $\mathrm{T}_{2}$. 
Table 2: Effects of urea application on soil physical properties at the end of harvest of maize at Site 1 and 2

\begin{tabular}{lccccl}
\hline Treatments & $\begin{array}{c}\text { Moisture } \\
\text { content } \\
(\%)\end{array}$ & $\begin{array}{c}\text { Bulk } \\
\text { density } \\
(\mathrm{g})\end{array}$ & $\begin{array}{c}\text { Total } \\
\text { porosity } \\
(\%)\end{array}$ & $\begin{array}{c}\text { Infiltration } \\
\text { rate } \\
(\mathrm{cm} / \mathrm{hr})\end{array}$ & Textural Class \\
\hline & & & SITE $\mathbf{1}$ & & \\
$\mathrm{T}_{0}$ & $25.64 \mathrm{~b}$ & $1.26 \mathrm{~b}$ & $50.51 \mathrm{a}$ & $20.58 \mathrm{a}$ & Sandy clay Loam \\
$\mathrm{T}_{1}$ & $36.65 \mathrm{a}$ & $1.25 \mathrm{~b}$ & $51.45 \mathrm{a}$ & $16.08 \mathrm{~b}$ & Sandy clay Loam \\
$\mathrm{T}_{2}$ & $36.53 \mathrm{a}$ & $1.34 \mathrm{a}$ & $47.69 \mathrm{~b}$ & $19.21 \mathrm{ab}$ & Sandy clay Loam \\
$\mathrm{T}_{3}$ & $39.76 \mathrm{a}$ & $1.36 \mathrm{a}$ & $46.87 \mathrm{~b}$ & $21.75 \mathrm{a}$ & Sandy clay Loam \\
& & & SITE 2 & & \\
$\mathrm{T}_{1}$ & $23.16 \mathrm{c}$ & $1.23 \mathrm{a}$ & $51.84 \mathrm{a}$ & $21.15 \mathrm{c}$ & Sandy loam \\
$\mathrm{T}_{2}$ & $27.81 \mathrm{~b}$ & $1.21 \mathrm{a}$ & $53.53 \mathrm{a}$ & $26.51 \mathrm{a}$ & Sandy loam \\
$\mathrm{T}_{3}$ & $26.69 \mathrm{~b}$ & $1.24 \mathrm{a}$ & $51.32 \mathrm{a}$ & $24.73 \mathrm{ab}$ & Sandy loam \\
\hline
\end{tabular}

Means followed by the same letters are not significantly ( $>0.05)$ different according to Duncan's Multiple Range Test. where $\mathrm{T}_{0}=$ control, $\mathrm{T}_{1}=60 \mathrm{~kg} / \mathrm{ha}, \mathrm{T}_{2}=30: 30 \mathrm{~kg} / \mathrm{ha}, \mathrm{T}_{3}=30: 20: 10 \mathrm{~kg} / \mathrm{ha}$

\section{Effects of split urea applications on soil chemical properties at the end of harvest of maize:}

The effects of split urea application on soil chemical properties at the end of harvest of maize are presented in Table 3 for Sites 1 and 2 respectively. At both sites, there was no significant ( $>$ 0.05 ) difference in the organic carbon and organic matter contents between $T_{2}$ and $T_{3}$ but they were significantly $(\mathrm{p}>0.05)$ higher than the remaining treatments. The $\mathrm{pH}$ values in the control at both sites were significant $(p>0.05)$ higher than the other treatments while there was no significant $(p>$ 0.05) difference between the other treatments which is in line with findings by Li et al. [10] Zhong et al. [8]. The results at Site 1 were the same as those of Site 2 with regards to total $\mathrm{N}$ contents. There were significant $(p>0.05)$ differences between all the treatments. Treatment $T_{3}$ gave the highest total $\mathrm{N}$ content while the control had the least. The second best was $\mathrm{T}_{2}$. For both Sites, the available $\mathrm{P}$ and $\mathrm{K}$ content was similar. $\mathrm{T}_{3}$ recorded the highest value for available $\mathrm{P}$ while there was no significant ( $p>0.05$ ) difference between the other treatments. The $\mathrm{K}$ contents for all the treatments were not significantly $(\mathrm{p}>0.05)$ different from each other. The $\mathrm{Ca}, \mathrm{Mg}$ and $\mathrm{Na}$ contents at both Site 1 and 2 were not significantly $(\mathrm{p}>0.05)$ different from one another. This means that urea application had no effect on the contents of exchangeable cations of the soil. There was no significant $(p>0.05)$ difference with regard to CEC arising from the application of urea fertilizer at both sites. The control gave the highest with regard to base saturation while there was no significant $(p>0.05)$ difference among the other treatments at site 1 . At site $2 T_{2}$ gave the highest value for base saturation while $T_{1}$ and $\mathrm{T}_{3}$ gave the least. There was no significant $(\mathrm{p}>0.05)$ difference in the $\mathrm{C} / \mathrm{N}$ ratio for both Site1 and 2.

Table 3: Effects of urea applications on soil chemical properties at the end of harvest of maize at Site 1 and 2

\begin{tabular}{|c|c|c|c|c|c|c|c|c|c|c|c|}
\hline $\begin{array}{l}\text { Treat- } \\
\text { ments }\end{array}$ & $\begin{array}{cc}\mathrm{t}- & \mathrm{OC} \\
\mathrm{ts} & (\%)\end{array}$ & Soil & $\mathrm{N}$ & $\mathrm{P}_{(\%}$ & $\mathrm{K}$ & $\begin{array}{r}\mathrm{Ca} \\
(\mathrm{mg} / \mathrm{kg})\end{array}$ & $\mathrm{Mg}$ & $\mathrm{Na}$ & $\begin{array}{l}\text { CEC } \\
--(\mathrm{cmol}\end{array}$ & $\begin{array}{c}\mathrm{BS} \\
1 / \mathrm{kg})-\end{array}$ & $\begin{array}{l}\mathrm{C} / \mathrm{N} \\
---(\%)\end{array}$ \\
\hline & \multicolumn{11}{|c|}{ SITE 1} \\
\hline \multirow[t]{2}{*}{$\mathrm{T}_{0}$} & $1.38 b$ & $6.79 a$ & $0.26 \mathrm{~d}$ & $17.44 \mathrm{~b}$ & $0.18 \mathrm{a}$ & $3.83 \mathrm{a}$ & $1.91 \mathrm{a}$ & $0.33 a$ & $6.45 \mathrm{a}$ & $96.49 a$ & $5.19 a$ \\
\hline & $1.47 \mathrm{~b}$ & $6.41 b c$ & $0.31 \mathrm{c}$ & $17.79 \mathrm{~b}$ & $0.18 \mathrm{a}$ & $3.93 \mathrm{a}$ & $1.96 \mathrm{a}$ & 0 & $6.69 a$ & 95. & $51 \mathrm{a}$ \\
\hline $\mathrm{T}_{2}$ & $1.88 \mathrm{a}$ & $6.45 b$ & $0.32 b$ & $17.44 \mathrm{~b}$ & $0.18 \mathrm{a}$ & $3.90 \mathrm{a}$ & $1.95 \mathrm{a}$ & $0.33 \mathrm{a}$ & $6.36 \mathrm{a}$ & $95.88 b$ & $5.78 \mathrm{a}$ \\
\hline \multirow[t]{2}{*}{$\mathrm{T}_{3}$} & $1.89 \mathrm{a}$ & $6.36 \mathrm{c}$ & $0.38 \mathrm{a}$ & $23.02 \mathrm{a}$ & $0.19 \mathrm{a}$ & $3.96 \mathrm{a}$ & $1.99 \mathrm{a}$ & $0.33 \mathrm{a}$ & $6.77 a$ & $95.81 b$ & $5.44 \mathrm{a}$ \\
\hline & \multicolumn{11}{|c|}{ SITE 2} \\
\hline $\mathrm{T}_{0}$ & $1.24 b$ & $6.29 a$ & 0.2 & 16.591 & b $\quad 0.1$ & $16 \mathrm{a} \quad 3.3$ & $1.60 \mathrm{~b}$ & $0.29 \mathrm{a}$ & $5.99 a$ & $96.09 \mathrm{~b}$ & $4.85 b$ \\
\hline $\mathrm{T}_{1}$ & $1.36 \mathrm{~b}$ & $5.69 b$ & 0.27 & $16.26 \mathrm{l}$ & & $14 \mathrm{a} \quad 3.6$ & $1.83 \mathrm{a}$ & $0.29 \mathrm{a}$ & $6.12 \mathrm{a}$ & $95.55 \mathrm{c}$ & $5.40 \mathrm{ab}$ \\
\hline $\mathrm{T}_{2}$ & $1.63 \mathrm{a}$ & $5.71 b$ & 0.291 & 17.811 & $b \quad 0.2$ & $21 \mathrm{a} \quad 3.5$ & $1.79 \mathrm{a}$ & $0.30 \mathrm{a}$ & a $\quad 6.03 a$ & $96.54 \mathrm{a}$ & $6.10 \mathrm{a}$ \\
\hline $\mathrm{T}_{3}$ & $1.77 \mathrm{a}$ & $5.77 \mathrm{~b}$ & 0.34 & 20.74 & & 3.57 & $1.78 \mathrm{a}$ & $0.31 \mathrm{a}$ & a $\quad 6.07 \mathrm{a}$ & $95.85 \mathrm{bc}$ & $5.72 \mathrm{ab}$ \\
\hline
\end{tabular}

Means followed by the same letters are not significantly ( $>0.05)$ different according to Duncan's Multiple Range Test. where $T_{0}=$ control, $T_{1}=60 \mathrm{~kg} / \mathrm{ha}, \mathrm{T}_{2}=30: 30 \mathrm{~kg} / \mathrm{ha}, \mathrm{T}_{3}=30: 20: 10 \mathrm{~kg} / \mathrm{ha}$. 


\section{Effects of split urea application on maize (Zea Mays L.) Plant Biomass and Yield:}

Tables 4 shows the effects of urea application on maize biomasses and grain yield for Sites 1 and 2 respectively. The treatment $T_{2}$ (Urea, 30:30 kg/ha) and $T_{3}$ (Urea, 30:20:10 kg/ha) gave the highest wet and dry plant shoot biomass while treatments $T_{1}$ (Urea $60 \mathrm{~kg} / \mathrm{ha}$ ) and the control gave the lowest plant biomass for Site 1 . On Site $2, \mathrm{~T}_{2}$ gave the highest wet and dry plant shoot biomass while there was no significant (P 0.05) difference between the other treatments. On Site 1, treatments containing urea were not significantly different from each other but were better than the control with regards to the wet root biomass. However, for the dry root biomass, $\mathrm{T}_{1}$ gave the highest value while control recorded the lowest. There was no significant $(\mathrm{P}>0.05)$ difference between all the treatments containing urea for both the wet and dry root biomass but they were all better than the control at Site 2. The same trend was observed for both sites as regards weight of cobs. The treatment $\mathrm{T}_{3}$ gave the highest maize grain yield while the control gave the least. The weight of wet grain at Site 1 was similar to that of Site 2 . Treatments $\mathrm{T}_{2}$ and $\mathrm{T}_{3}$ gave the highest wet grain yields while the control gave the least. The treatment $T_{3}$, however, gave the highest value with regard to weight of dry grains at both Sites while the control recorded the least. Both Sites gave similar results with regard to 1000 grain weight. The highest value was recorded for treatment $T_{2}$ and $T_{3}$ while the least was in the control. This observation can be attributed to Nitrogen being an essential element of all the amino acids in plant structures which are the building blocks of plant proteins, important in the growth and development of vital plant tissues and cells like the cell membranes and chlorophyll and is important in plant processes such as photosynthesis. Thus, plants with sufficient nitrogen will experience high rates of photosynthesis and typically exhibit vigorous plant growth and development as well as yield. This is in line with researches by Obidiebube et al. [16] who reported high maize yield at different rate of NPK as well as Angayarkanni and Ravichandran [20] who reported highest yield in rice with split urea fertilizer application.

Table 4: Effects of urea applications on maize plant biomass and grain yield at Site 1 and 2

\begin{tabular}{|c|c|c|c|c|c|c|c|c|}
\hline Treatments & $\begin{array}{l}\text { Wet } \\
\text { shoot } \\
\text { biomass }\end{array}$ & $\begin{array}{l}\text { Dry } \\
\text { shoot } \\
\text { biomass }\end{array}$ & $\begin{array}{l}\text { Wet } \\
\text { root } \\
\text { biomass }\end{array}$ & $\begin{array}{l}\text { Dry } \\
\text { root } \\
\text { biomass }\end{array}$ & $\begin{array}{l}\text { Weight } \\
\text { of cob }\end{array}$ & $\begin{array}{l}\text { Weight } \\
\text { of wet } \\
\text { grain }\end{array}$ & $\begin{array}{l}\text { Weight } \\
\text { of dry } \\
\text { grain }\end{array}$ & $\begin{array}{l}1000 \\
\text { grain } \\
\text { weight }\end{array}$ \\
\hline \multicolumn{9}{|c|}{ SITE 1} \\
\hline $\mathrm{T}_{0}$ & $134.08 b$ & $34.78 \mathrm{c}$ & $38.68 b$ & $26.74 \mathrm{c}$ & $189.78 d$ & $120.59 \mathrm{c}$ & $49.39 \mathrm{c}$ & $89.77 \mathrm{c}$ \\
\hline $\mathrm{T}_{1}$ & $142.40 \mathrm{~b}$ & $36.94 b$ & $40.78 b$ & $31.67 \mathrm{a}$ & $275.63 c$ & $167.63 b$ & $66.59 \mathrm{bc}$ & $116.89 b$ \\
\hline $\mathrm{T}_{2}$ & $178.44 \mathrm{a}$ & $42.71 \mathrm{a}$ & $43.48 \mathrm{a}$ & $28.08 b c$ & $292.24 b$ & $198.23 a$ & 79.94ab & $139.70 \mathrm{a}$ \\
\hline $\mathrm{T}_{3}$ & $130.99 b$ & $42.58 \mathrm{a}$ & $44.83 a$ & $29.09 \mathrm{~b}$ & $315.97 a$ & $207.20 \mathrm{a}$ & $93.81 \mathrm{a}$ & $142.67 \mathrm{a}$ \\
\hline \multicolumn{9}{|c|}{ SITE 2} \\
\hline $\mathrm{T}_{0}$ & $134.33 b$ & $37.00 \mathrm{~b}$ & $36.78 b$ & $20.39 b$ & $161.43 d$ & $97.23 \mathrm{c}$ & $40.83 c$ & $82.90 \mathrm{c}$ \\
\hline $\mathrm{T}_{1}$ & $139.84 b$ & $38.39 b$ & $39.97 \mathrm{a}$ & $26.47 \mathrm{a}$ & $239.08 \mathrm{c}$ & $146.02 b$ & $58.31 \mathrm{~b}$ & $107.99 b$ \\
\hline $\mathrm{T}_{2}$ & $165.02 \mathrm{a}$ & $42.56 a$ & $41.68 \mathrm{a}$ & $24.57 \mathrm{a}$ & $266.21 b$ & $173.92 \mathrm{a}$ & $62.09 \mathrm{~b}$ & $120.39 a$ \\
\hline $\mathrm{T}_{3}$ & $162.34 \mathrm{a}$ & $41.57 \mathrm{a}$ & $41.97 \mathrm{a}$ & $24.21 \mathrm{a}$ & $285.28 \mathrm{a}$ & $179.50 \mathrm{a}$ & $76.96 a$ & 114.18ab \\
\hline
\end{tabular}

Means followed by the same letters are not significantly ( $\mathrm{p}>0.05)$ different according to Duncan's Multiple Range Test. where $\mathrm{T}_{0}=$ control, $\mathrm{T}_{1}=60 \mathrm{~kg} / \mathrm{ha}, \mathrm{T}_{2}=30: 30 \mathrm{~kg} / \mathrm{ha}, \mathrm{T}_{3}=30: 20: 10 \mathrm{~kg} / \mathrm{ha}$.

\section{Conclusion}

Fertilizer application as a means of boosting productivity could pose as an environmental hazard when applied as a single dose, particularly nitrogen fertilizers. This is so because nitrogen is very mobile and a lot of things happen to it when it enters the soil. It can leach into underground water or be eroded with moving water; it can volatilize and contribute to greenhouse effect. It can also be taken up by weeds or fixed in bodies of soil microbes. Consequently, plants are left with little for their metabolism. Spliting of Urea fertilizer can be a means to attenuate this situation. Spliting of 
Urea fertilizer improved soil nutrient status thereby improving maize yield. Hence, to reduce wastage and also reduce environmental pollution due to excessive fertilizer application (Euthrophication), Split application of Urea Fertilizer and other N fertilizer should be adopted.

\section{References}

[1] C. Baffi et al., Determination of biological stability in compost: A comparison of methodologies, Soil Biol. Biochem. 39 (2007) 1284-1293.

[2] R.H. Bray, L.T. Kurtz, Determination of Total Organic and Available Forms of Phosphorus in Soils. Soil Science. 59 (1945) 39-45.

[3] R. Cruse, Agriculture: Is climate change a serious issue? Agrociencia. 16 (2012) 9-19.

[4] H. Eswaran, R. Lal, P.F. Reich. 2001. Land degradation: an overview, in: E.M. Bridges et al. (Eds.), Responses to Land Degradation, Proceedings of the 2nd. International Conference on Land Degradation and Desertification. Khon K., January 1999. New Delhi: Oxford Press.

[5] R.J. Flotats, MF. Solé, Situación actual en el tratamiento de los residuos orgánicos: Aspectos científicos, económicos y legislativos, In: J. Moreno C., R. Moral H. (Eds.), Compostaje. Mundi-Prensa. Madrid, España, 2008, pp. 44-73.

[6] J. Gilluly, A.C. Waters, A.O. Woodford, Principles of Geology (4th ed.), 1975.

[7] G.R. Hallberg, D.R. Keeney 1993, Nitrate, Alley, William A., ed., Regional Ground-water Quality, Van Nostrand Reinhold, New York, p.297-322.

[8] H. Zhong et al., Effects of Different Nitrogen Applications on Soil Physical, Chemical Properties and Yield in Maize (Zea mays L.), Agricultural Sciences. 5 (2014) 1440-1447.

[9] T. Hernández et al., Organic wastes as alternative to inorganic fertilizers in crop cultivation International symposium on almonds and pistachios, 2014

[10] Q. Li et al., Cumulative Effects of a 17-Year Chemical Fertilization on the Soil Quality of Cropping System in the Loess Hilly Region, China, Journal of Plant Nutrition and Soil Science. 176 (2013) 249-259.

[11] S.S. Malik et al., Influence of Organic and Synthetic Fertilizers on Soil Physical Properties, Int. J. Curr. Microbiol. App. Sci. (3(8) 2014) 802-810.

[12] Mother Nature Network, 2009. Acid rain: What causes it and what effect does it have.

[13] A. Niang et al., Soil fertility replenishment and recapitalization project in western Kenya. Progress report, February 1997- July 1998. Pilot Project Report No. 8. Regional Agroforestry Research Centre, Maseno, Kenya, 1998.

[14] K.D. Shepherd, M.J. Soule, Soil fertility management in West Kenya: dynamic simulation of productivity, profitability and sustainability at different resource endowment levels, Agriculture, Ecosystems and Environment. 71 (1998) 131-146.

[15] A. Tarigo, C. Repetto, D. Acosta, Evaluación agronómica de biofertilizantes en la producción de lechuga (Lactuca sativa) a campo. Tesis de Licenciatura Universidad de la Republica Facultad de Agronomía. Montevideo, Uruguay, 2004.

[16] E.A. Obidiebube et al., Effect of Different Levels of NPK $(15: 15: 15)$ on the Growth and Yield of Maize in Rainforest Agro-ecological Zone, Int. J. Agric. Sci. 2(12) (2012)1103-1106.

[17] H.K. Obied et al., Bioactivity and analysis of biophenols recovered from olive mill waste, J. Agric. Food Chem. 53 (2005) 823-837

[18] University of Maryland Center for Environmental Science. Aquatic 'dead zones' contributing to climate change. ScienceDaily, 12 March 2010. Available: www.sciencedaily.com/releases/2010/03/100311141213.htm.

[19] F. Zucconi et al., Evaluating toxicity of inmature compost, BioCycle. 22 (1981) 54-57.

[20] A. Angayarkanni, M. Ravichandran, Judicious fertilizer N split for higher use efficiency in transplanted rice. Indian Journal of Agricultural Research. 35(4) (2001) 278-280. 